\title{
Rehabilitacja zabytków architektonicznych, na przykładzie adaptowanych obiektów folwarcznych do celów kulturalnych i socjalnych w Brzegu Dolnym
}

\author{
Małgorzata Doroz-Turek \\ e-mail:mdoroz@tu.kielce.pl \\ Politechnika Świętokrzyska, Wydział Budownictwa i Architektury, Katedra Architektury i Urbanistyki
}

\begin{abstract}
Streszczenie: Tematem artykułu jest rehabilitacja zabytków przeznaczonych do adaptacji na nową funkcję, odmienną od pierwotnego użytkowania. W przypadku adaptacji starych budynków, zabytków architektury, jest ona „dokonywana przeważnie w ramach kompleksowych działań konserwatorsko-restauracyjnych", a rehabilitacja związana jest z gruntownym remontem zazwyczaj tymczasowo użytkowanych, albo opuszczonych i zaniedbanych obiektów, w dostatecznym lub bardzo złym stanie technicznym.

Autorka ukazuje rehabilitację i adaptację, jako działania konserwatorskie, w których ogromną rolę, oprócz projektowych, odgrywają działania inżynierskie mające na celu poprawę stanu obiektu zabytkowego, ale z zachowaniem głównych zasad konserwatorskich.

Artykuł o rehabilitacji poświęcono głównie budynkowi Gołębnik z wieżą, składającemu się na dawny Folwark założenia pałacowego w Brzegu Dolnym, przy projekcie którego udział brała autorka.
\end{abstract}

Słowa kluczowe: architektura, rehabilitacja, zabytek, rewaloryzacja, adaptacja

Zagrożeniem dla prawidłowego funkcjonowania człowieka jest utrata zdrowia, sprawności fizycznej i psychicznej. Integralną częścią leczenia, procesu terapeutycznego jest rehabilitacja. Rehabilitacja, (tac. re - znów, na nowo, przeciw; habilis - sprawny, należyty, stosowny), znaczy przywrócenie choremu aktywności na skutek wyleczenia lub przez fizyczne i psychiczne przystosowanie go zmienionych warunków życia ${ }^{1}$. Realnym niebezpieczeństwem dla architektury, funkcjonowania obiektu jest utrata trwałości technicznej, funkcji - użyteczności oraz walorów estetycznych, tzw. triady witruwiańskiej. Ratunkiem, jeśli nie było odpowiedniej ochrony i konserwacji lub metody te stały się niewystarczające, pozostaje zastosowanie odpowiednich działań ukierunkowanych na przywrócenie wszelkich wartości mających znaczenie w przedłużeniu trwania zabytku², ale przede wszystkim, które pozwolą tchnąć w obiekt "nowe” życie. I tak jak w leczeniu rehabilitacja, jako proces medyczno-społeczny, stała się nieodzowną składową rozwoju socjalnego każdego nowoczesnego kraju ${ }^{3}$, także w ochronie i konserwacji zabytków „rehabilitacja”, jako metoda interwencyjna ma ogromne znaczenie na istnienie, ale także na „ewolucję" zabytków.

Do globalnych społecznych procesów należy ochrona dziedzictwa kulturalnego. W ochronie i konserwacji zabytków od wieków zachodzą zmiany, które szczególnie daleko zaszły w XX w., kiedy konieczne było wprowadzenie coraz bardziej interwencyjnych metod "rehabilitacyjnych". Interwencja nie jest sprzeczna z założeniami ochrony zabytków, tak jak i użyteczność. Dlatego ewolucja metod konserwatorskich w ochronie środowiska kulturowego podąża ku coraz większej interwencji i doprowadza do tego, że kolejny kroki postępują ku rozwijaniu działań konserwatorskich. Do już interwencyjnego działania, jakim oprócz konserwacji jest restauracja, 
(podejmowanego w stosunku do zabytków zdewastowanych zarówno technicznie jak i estetycznie ${ }^{4}$ ) dochodzi rewaloryzacja. Rewaloryzacja to działanie o szerokim spektrum zabiegów, także tych prac poza konserwatorskich, jak : dobudowa, rozbudowa, a także przebudowa, wszystkie dotykają już aspektu adaptacji i modernizacji, czyli przemiany struktury zabytku. Celem rewaloryzacji, tak zwanej rehabilitacji jest przywrócenie utraconych "wartości artystycznych, kulturowych, technicznych i użytkowych poprzez działania prawne, konserwatorskie i restauracyjne, podejmowane w celu stworzenia możliwości funkcjonowania dobra kultury (najczęściej zabytku) we wspótczesnym organizmie społecznym" ${ }^{5}$, według współczesnej definicji podanej przez Prof. Iwony M. Szmelter.

\section{Dzieje miasta Brzeg Dolny}

Brzeg Dolny (niem. Dyhernfurth, Stand Und der Sitz der Gemeinde, Kr. Wohlau) to jedno z wielu historycznych miast w województwie dolnośląskim. Miasto położone jest na prawym brzegu Odry, w odległości 31 km na północny-zachód od Wrocławia, stanowiąc tym samym przedłużenie miejsko-przemysłowej aglomeracji wrocławskiej.

Pierwsza wzmianka o osadzie Brieg pochodzi z dokumentu z 1223 roku. Kolejną informację z połowy XIV stulecia, z 1353 r., zawiera sporządzony dla celów podatkowych, z polecenia cesarza Karola IV „Rejestr wsi, folwarków i praw księstwa wrocławskiego i okręgu namysłowskiego", popularnie zwany „Księgą ziemską księstwa wrocławskiego". Z tej informacji źródłowej wiadomo, że Brzege posiadał wówczas 1,5 łanu ziemi, jeden młyn nad Odrą i jeden mały młyn, z jednym kołem w bliżej nie oznaczonym miejscu. Może to świadczyć o niewielkim wówczas znaczeniu gospodarczym osady, będącej pierwotnie folwarkiem wsi leżącej na przeciwnym brzegu Odry, należącym do panów na Głoskowie, (obec. wieś Głoska). Polską nazwę miejscowości Brzeg - osady położonej nad brzegiem Odry - podkreśla nawet niemiecka literatura historyczna. Ze względu na położenie ludność osady trudniła się głównie flisactwem i rybołówstwem. W związku z tym istniała tutaj przeprawa promowa przez Odrę, a wiemy o niej z przekazów z roku 1491.

Nad Odrą wybudowano najokazalszy zabytek miasta Brzegu Dolnego - założenie pałacowe, którego historia zaczęła się ponad pięćset lat temu. Pierwszy opis istniejącej rezydencji pochodzi z roku 1638, z czasu kiedy trwała wojna trzydziestoletnia (1618-1648), ${ }^{6} \mathrm{~W}$ drugiej połowie XVII wieku fundatorem przebudowy rezydencji na barokowy pałac jest hrabia von Dyhern. Georg Abraham von Dyhern ${ }^{7}$, po kilku stuleciach, kiedy właścicielami miejscowości najczęściej były rody von Hugwitz (od 1355 r.) i von Falkenhayn ${ }^{9}$ (w latach 1453-1528), przejmuje osadę w 1660 roku. Przyczynił się także do otrzymania dla Brzegu Dolnego, od cesarza Leopolda I, praw miejskich w roku 1663.

Schyłek wieku XVIII to kolejne ożywienie w historii miasta, po tym jak w roku 1767 jego właścicielem zostaje minister Śląska i Prus Południowych - Karl Georg von Hoym. W posiadanie Brzegu Dolnego wszedł poprzez ożenek z baronówną Antonią Louise von Dyhrn und Schönau. Nowy właściciel przystępuje między innymi do przekształcenia majątku: barokowej założenia pałacowego i parku. Około 1785 r. przebudowuje pałac w stylu klasycystycznym (ryc. 1), według projektu i pod kierunkiem śląskiego architekta Carla Gottharda Langhansa ${ }^{10}$. Architekt dodał dwa boczne skrzydła oraz obok pałacu, w tym samym stylu w drugiej połowie XVIII w., wybudował oficynę pałacową. Rozpoczęta przez von Hoym modernizacja posiadłości zakończona została dopiero ok. 1800 roku.

Kolejnej przebudowie rezydencja została poddana w połowie XIX wieku, za sprawą hrabiny Toni von Lazareff-Hoym, która nadała elewacjom obiektu kostium francuskiego neorenesansu, dodano szczyty wieżyczki, szpiczaste hełmy (ryc. 2). 
Oficyna, tzw. „mały pałac”, do obecnych czasów nie uległa zmianie, w przeciwieństwie do pałacu (pożar w lutym 1945 r.). Nieopodal założenia rezydencjonalnego funkcjonował także browar oraz folwark, należący do właścicieli miasta.

W styczniu 1945 roku dolnobrzeski pałac opuścił, ostatni z rodu Hoymów, hrabia Thassilo von Saurma-Hoym wraz z rodziną. Miesiąc później obiekt spłonął, najprawdopodobniej podpalony przez żołnierzy Armii Czerwonej. Po tym wydarzeniu do odbudowy pałacu przystąpiono na początku lat 50. XX wieku. Pałac otrzymał zmienioną, uproszczoną formę. W tym kształcie przetrwał do czasów współczesnych, będąc w rękach Państwa i gminy Brzeg Dolny.
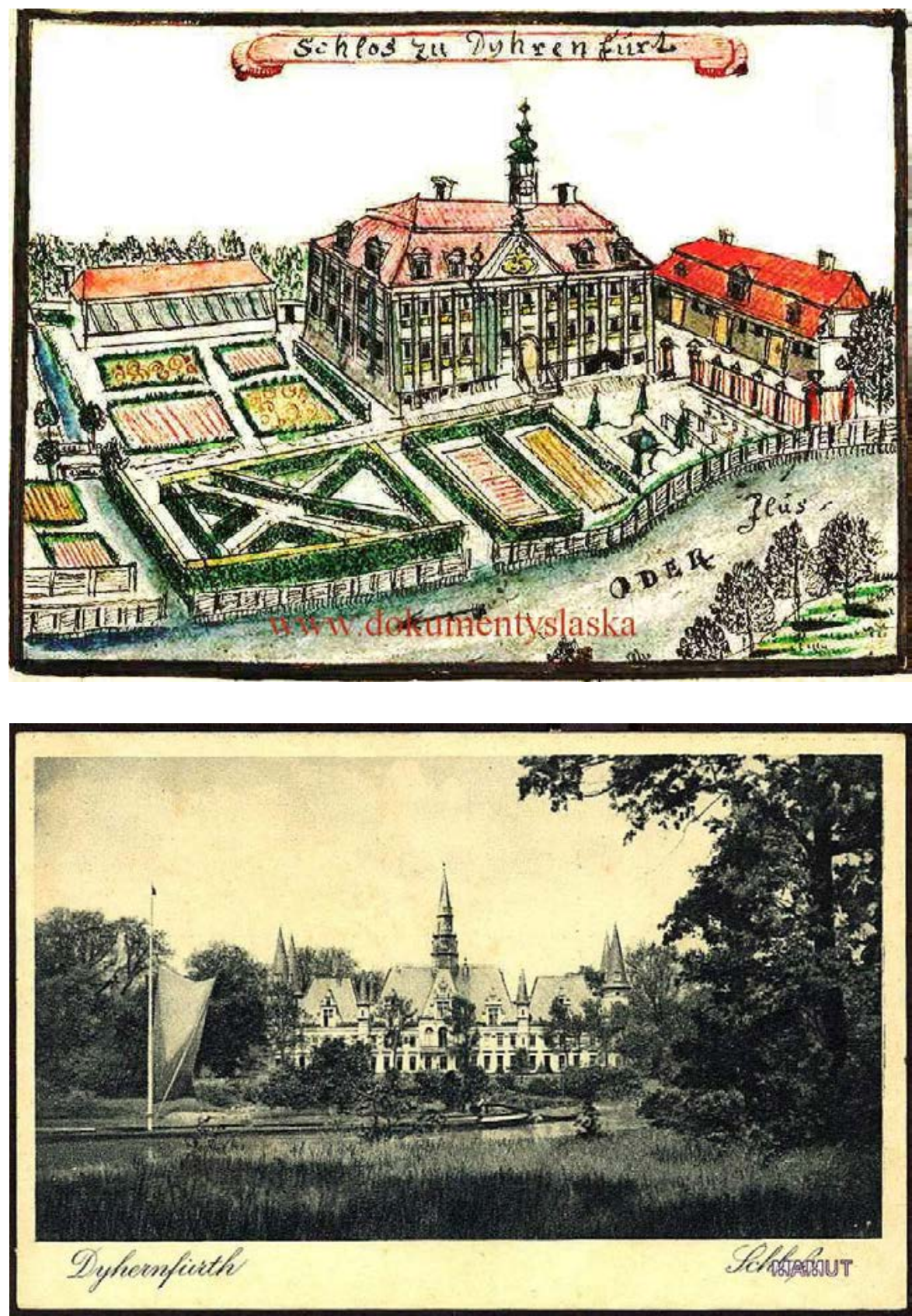

Ryc. 1. Fryderyk Bernard Wernher, Widok Pałacu w Brzegu Dolnym z lotu ptaka, ok. 1740 r. [Archiwum Wrocławskie]

Fryderyk Bernard Wernher, View of the Palace of the Brzeg Dolny bird's eye view, approx. 1740.

Ryc. 2. Pałac rodu von Hoym w Brzegu Dolnym przed 1945 r. [Archiwum Wrocławskie]

Palace of the von Hoym in Brzeg Dolny before 1945. 


\section{Czasy współczesne Brzegu Dolnego}

Miasto Brzeg Dolny i jego zabytki uległy zniszczeniu w roku 1997. Dotknięte zostały wówczas wielką powodzią, zw. tysiącleciaa ${ }^{11}$, która nawiedziła między innymi województwo dolnośląskie. Skutki naturalnego kataklizmu były ogromne, ale mimo zarówno ludzkiej tragedii, jak i materialnych strat zaraz po ustąpieniu wody przystąpiono do usuwania zniszczeń. Pierwsze pieniądze rozporządzono na usuwanie skutków powodzi, kolejne przyznane środki finansowe przeznaczono na remonty i odbudowę miasta, w tym remont zabytków - historycznych obiektów. Odbudowa miasta trwała trzy lata (lata 1997-2000), dzięki niej odnowiono i unowocześniono zaniedbane dotąd Stare Miasto Brzegu Dolnego oraz wyremontowano zabytki.

W Brzegu Dolnym jest kilka godnych uwagi zabytkowych obiektów, ale przede wszystkim, wzmiankowany w zarysie historii miasta, mający znaczenie w jego strukturze i sylwecie - Pałac rodu von Hoym wraz z Bocznym Pawilonem. Zespół pałacowy, będący własnością gminy Brzeg Dolny, z uwagi na lokalizację przy brzegu Odry, znacznie ucierpiał w trakcie powodzi w 1997 roku. Stan dawnej oficyny był na tyle zły, że był pomysł jej rozebrania. Na szczęście do tego nie doszło. Razem z pałacem, za przyznane dodatkowe dotacje, zostały po powodzi w ciągu trzech lat wyremontowane. W wyniku prac rehabilitacyjnych dawny pałac adaptowano na siedzibę Dolnośląskiego Ośrodka Kultury, zaś oficynę pałacową, zw. Mały pałac przeznaczono na "nową" siedzibę Urzędu Miejskiego.

W trakcie powodzi zalaniu uległy także, usytuowane w bliskim sąsiedztwie pałacu, obiekty związane z zespołem pałacowym. Od strony wschodniej, wzdłuż koryta rzeki Odry, rozciąga się dawny Folwark. Na zabudowania składają się: Stajnia z Wozownią (1. ćw. XIX w.), ob. II i Gołębnik z wieżą (XIX/XX w.), ob. I (ryc. 3). Oba obiekty jeszcze do niedawna były mocno zaniedbane. Nie remontowane po powodzi cały czas niszczały narażone na wysoki poziom wód oraz w wyniku eksploatacji. Przez długi czas urząd wynajmował pomieszczenia do celów komercyjnych. W Wozowni pomieszczenia służyły funkcji handlowej i jako garaż, zaś w dawnym Gołębniku, jako garaże i zakład mechaniczny, tylko część wieżowa nie była zagospodarowana.

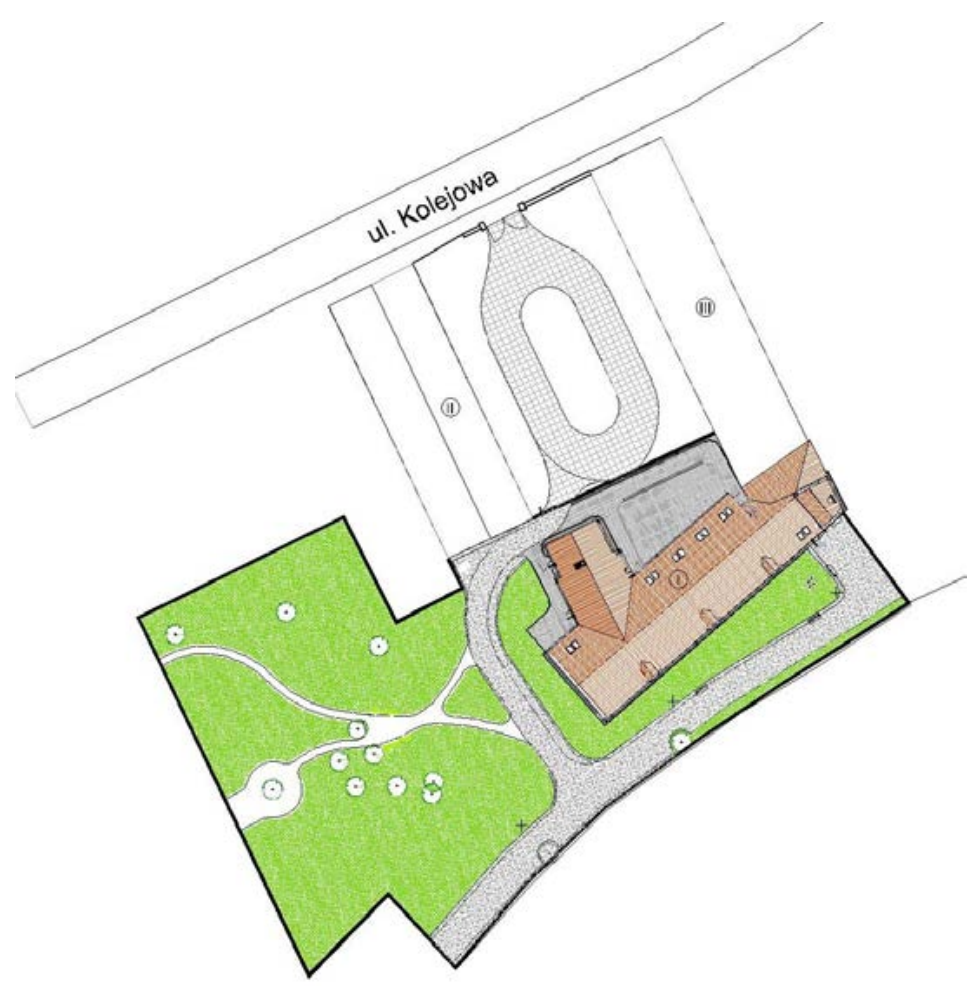

Ryc. 3. Sytuacja dawnego folwarku; Projekt wykonawczy, Rewitalizacja i adaptacja zabudowań dawnego folwarku (gotębnik) z przeznaczeniem na działalność Dolnobrzeskiego Ośrodka Kultury, główny projektant mgr inż. arch. Jacek Miller, rysunek Małgorzata Doroz-Turek, Wrocław 2011

The situation of the former farm; Executive project. Revitalization and adaptation of buildings of a former farm (dovecote) for the purpose of business Dolnobrzeskiego Cultural Centre, the chief designer arch. Jacek Miller, drawing Margaret Doroz Turek, Wroclaw 2011

11 Powódź nawiedziła w lipcu 1997 roku południową i zachodnią część Polski, Czechy, wschodnie Niemcy, północną i zachodnią Słowację, oraz wschodnią Austrię. 
Dolnobrzeski Dom Kultury borykał się z problemami lokalowymi na funkcję kulturalną. Władze miasta dostrzegły potencjał i możliwości wykorzystania istniejących obiektów dawnego Folwarku. Mimo poważnych uszkodzeń obu budynków pojawił się pomysł i postanowiono przeznaczyć je na cele: kulturalne i społeczne. Zdecydowało o tym także znaczenie terenu będącego w ścisłej strefie A w strefie ochrony konserwatorskiej oraz obserwacji archeologicznej, i znajdujących się pod ochroną Wojewódzkiego Konserwatora Zabytków obiektów daw. Folwarku. Obiekty są wpisane do wojewódzkiej ewidencji zabytków ${ }^{12}$. Z uwagi na to wstępne koncepcje i projekty: rewaloryzacji i adaptacji zabudowań dawnego folwarku - gołębnika i stajni z wozownią ${ }^{13}$ musiały być zaopiniowane przez Wojewódzkiego Konserwatora Zabytków we Wrocławiu ${ }^{14}$.

Temat o rehabilitacji autorka poświęca głównie budynkowi Gołębnik z wieżą w Brzegu Dolnym, na przykładzie własnego doświadczenia projektowego i realizacji, przy których brała udział ${ }^{15}$.

\section{Budynek gołębnika z wieżą, stan zastany Sytuacja}

Obiekt zlokalizowany jest na działce przy ulicy Kolejowej (ob. I, ryc. 3), na której znajduje się także budynek daw. stajni z wozownią, (ob. II, ryc. 3) oraz współczesny parterowy, socjalny budynek mieszkalny, (ob. III, ryc. 3). Teren oprócz sąsiedztwa od południowego-zachodu z wyżej opisanym założeniem pałacowym, od strony północno-zachodniej graniczy z ww. ulicą, od strony południowego-wschodu przylega do koryta rzeki Odry, zaś od strony północno-wschodniej sąsiaduje z zabudową jednorodzinną.

\section{Architektura}

Dawny gołębnik z przełomu wieków XIX/XX to parterowy obiekt kryty dwuspadowym dachem, wybudowany generalnie na planie wydłużonego prostokąta. Bryłę od wschodu zamyka, dominująca nad całością trzykondygnacyjna wieża, zaś zachodni narożnik poprzedza, skośnie dobudowane od północy skrzydło na nieregularnym, prostokątnym rzucie. Obiekt dostępny z poziomu terenu drzwiami oraz wrotami, prowadzącymi do poszczególnych części. Na poddasze prowadziły przyścienne, jednobiegowe, murowane z cegły schody, zlokalizowane w pomieszczeniu dostawionej, skośnej części budynku (ryc. 4, pom. 0.1).

Elewacje proste, dekoracja tylko w postaci kamiennego cokołu oraz prostego, profilowanego gzymsu pod okapem dachu. Oryginalne otwory okienne budynku niewielkie, zamknięte łukiem odcinkowym, bez opasek wokół, posiadały jedynie proste, profilowane gzymsy podparapetowe; większość okien została zmieniona lub wprowadzono nowe, przeważnie większe, w kształcie różnej wielkości prostokątów, także wtórne bramy (ryc. 8). Od strony Odry na dachu są mocno zniszczone, dekoracyjne lukarny (ryc. 9, 10). Na osi trzech elewacji wieży wysokie, ostrołucznie zamknięte otwory okienne; wtórnie zamurowane w celu wzmocnienia konstrukcji ścian tej wertykalnej części budynku. Stolarka okienna i drzwiowa drewniana, szyby w większości okien ze szprosami.

Wnętrze gospodarczego budynku utrzymane w surowym stylu. Jedyną funkcję ozdobną, oprócz konstrukcyjnej, spełniają podpierające podciąg stropu Kleina żeliwne słupy z dekoracyjnymi głowicami, drewniany słup z dekoracyjnymi, profilowanymi mieczami (ryc. 4, pom. 0/5) oraz ceglane sklepienia kolebkowe (ryc. 4, pom. 0/12-0/15).

12 Dawny Gołębnik wpisany jest do Rejestru Zabytków pod nr A/3028/716/W z dnia 2.11.1995 r. jest w wykazie obiektów w wojewódzkiej ewidencji zabytków.

13 Projekt budowlany i wykonawczy: Rewitalizacja i adaptacja zabudowań dawnego folwarku (stajnia z wozownia) z przeznaczeniem na działalność Gminnego Ośrodka Pomocy Społecznej, 2011.

14 Z tego czasu pochodzi też trzeci projekt: Odbudowa muru oporowego i bulwaru spacerowego w celu umożliwienia zainstalowania mobilnego zabezpieczenia przeciwpowodziowego w Brzeg Dolny, ogłoszony dn. 23 sierpnia 2011 roku.

15 Projekt budowlany i wykonawczy, Rewitalizacja i adaptacja zabudowań dawnego folwarku (gołębnik) z przeznaczeniem na działalność Dolnobrzeskiego Ośrodka Kultury, główny projektant mgr inż. arch. Jacek Miller, 2011 rok. 


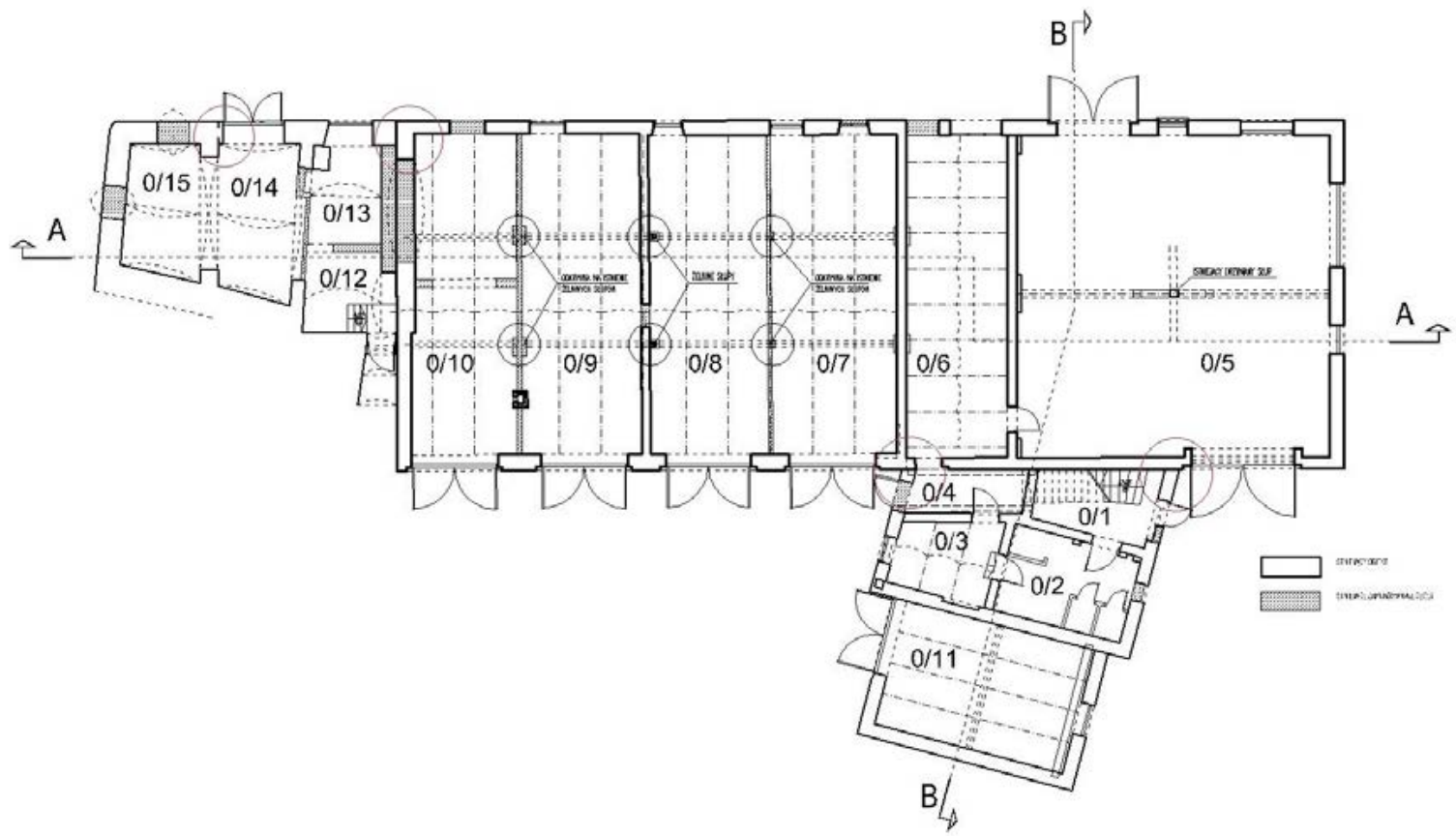

Ryc. 4. Rzut przyziemia. Inwentaryzacja, rysunek Małgorzata Doroz-Turek, Wrocław 2011

Ground plan. Stocktaking

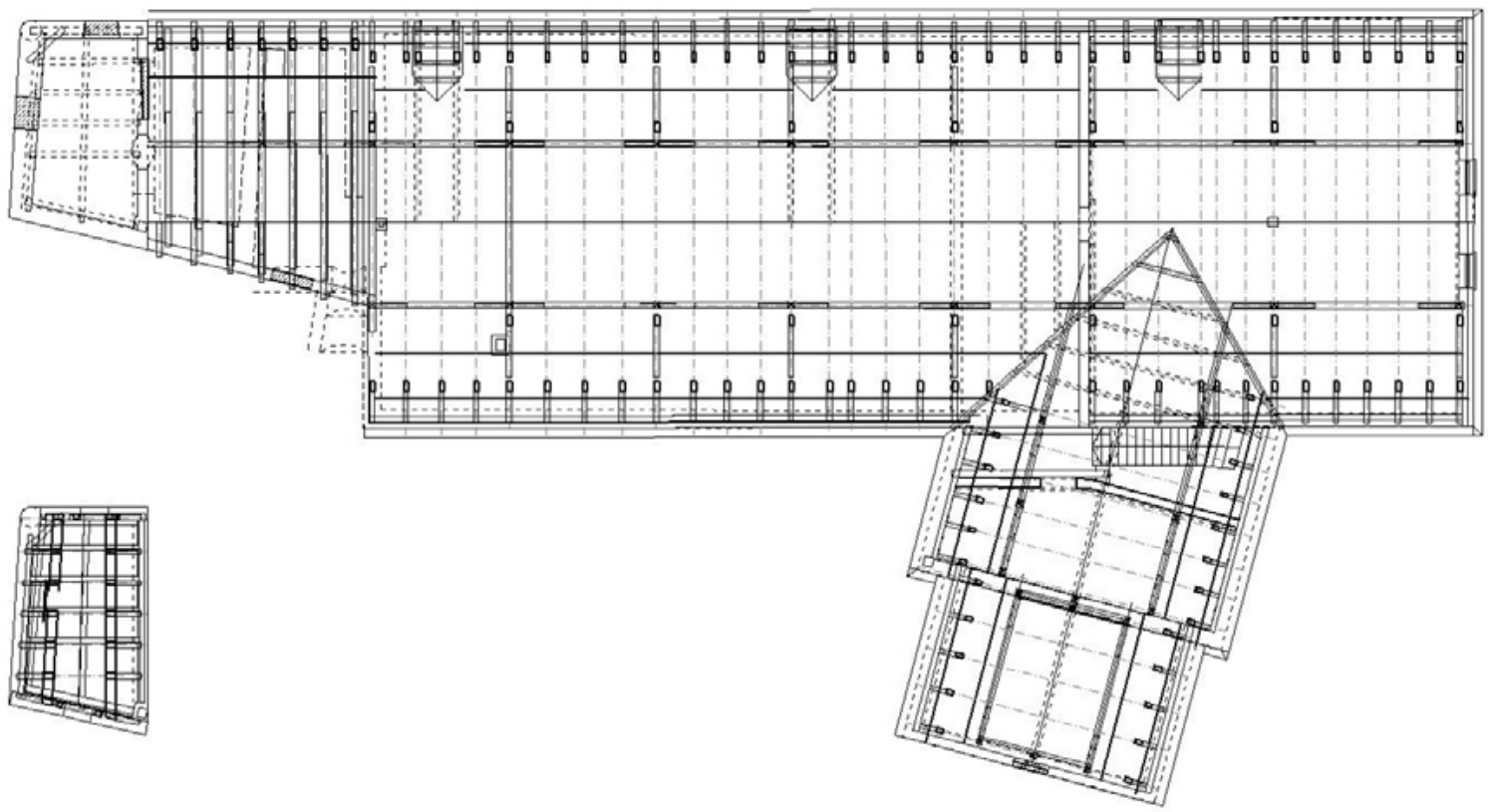

Ryc. 5. Rzut więźby dachowej. Inwentaryzacja, rysunek Małgorzata Doroz-Turek, Wrocław 2011

Throw the roof truss. Stocktaking. 


\section{Materiał, konstrukcja, technika}

Parterowy budynek, bez podpiwniczenia, z poddaszem nieużytkowym, wykonany w technologii tradycyjnej. Ściany nadziemne i część ścian fundamentowych murowane z ceramicznej cegły pełnej, na zaprawie wapiennej. Pozostała, większa część fundamentów z cokołem z kamienia (ryc. 6). Fundamenty o schodkowym przekroju ławy z odsadzkami, różnią się w poszczególnych częściach budynku oprócz materiału, jedynie proporcjami i głębokością osadzenia. Ściany na zewnątrz tynkowane, także wewnątrz, poza dwoma pomieszczeniami od wschodu, gdzie surowy wątek ceglany.

Na elementy nośne konstrukcji składają się zewnętrzne i wewnętrzne ściany murowane z cegły ceramicznej pełnej, o grubości 40-54 cm dla budynku oraz około 50-70 cm dla wieży. Ponadto występują wewnątrz żeliwne słupy (il. 4, pom. 0/7-0/10). Ceglane, kolebkowe sklepienia wprowadzono tylko w pomieszczeniach: pod wieżą oraz do niego przylegających (ryc. 4, pom. 0/12-0/15). W większości budynku, nad parterem, są podwójne stropy: niższa warstwa strop typu Kleina, nad nim - drewniany, belkowy, z drewnianą podłogą nieużytkowego poddasza (ryc. 4, pom. 0/3-0/4, 0/6-0/11). Nad największym pomieszczeniem tylko strop drewniany, belkowy (ryc. 4, pom. 0/5), z podciągiem na osi wnętrza, podpartym na środku ww. drewnianym słupem.

Nad budynkiem dwuspadowy dach, o kącie nachylenia połaci: nad główną częścią - 40 stopni, nad bocznym skrzydłem - około 45 stopni i nad wieżą - około 50-55 stopni. Dach głównej części budynku ma więźbę dachową kleszczowo-płatwiową, z przepustnicami, zaś północne skrzydło i wieża - krokwiowo-jętkową. Konstrukcję dachów pokrywa dachówka ceramiczna - karpiówka - ułożona podwójnie w łuskę. Na dachu części środkowej, od strony rzeki Odry, zachowały się trzy lukarny doświetlające strych, ujęte ozdobnymi obramieniami, w formie spływających wolut.

Osobny, dwuspadowy dach wieńczy trzykondygnacyjną wieżę, osadzoną na narożnikowym pomieszczeniu przyziemia, na planie nieforemnego prostokąta (ryc. 4, pom. 0/15; ryc. 5). Dach dwuspadowy założony na osi północ-południe, pomiędzy dwoma schodkowymi szczytami, ma podkreślony południowo-wschodni narożniki poprzez wprowadzoną okrągłą wieżyczkę. Ponadto na wschodniej połaci jest ozdobna lukarna z miedzi (ryc. 11), a na kalenicy dachu grzebień. Na widokową wieżę wchodziło się drewnianymi schodami. Konstrukcja drewnianej klatki schodowej nie przetrwała - choć układ biegów i spoczników schodowych zachował się wewnątrz, w postaci odciśniętych śladów na powierzchni zniszczonych murów.

\section{Wnioski badań formy}

Z przeprowadzonej inwentaryzacji budynku oraz analizy konstrukcji murów wynikło, że istniejący obiekt nie powstał w jednym czasie. Pierwotną formą była środkowa część budynku na planie wydłużonego prostokąta. Do głównego budynku została od wschodu dobudowana część z wieżą; świadczy o tym m.in. ślad po zamurowanej bramie we wschodnim murze. Prawdopodobnie sama wieża została wybudowana osobno, a pomiędzy nią i istniejącym już budynkiem wprowadzono łącznik, na co wskazują nie tylko wspomniany zamurowany otwór bramny, ale widoczne na zewnętrznym licu elewacji szwy, czyli brak jednolitego przewiązania muru na zewnętrznym licu elewacji, w miejscach dostawionej murowanej ściany do już istniejącej stojącego tu obiektu. Dobudowane zostało także skośne skrzydło (ryc. 4). Można się także pokusić o hipotezę, że pierwotny budynek został także rozbudowany o zachodnią część, tj. o pomieszczenia 0/5 i 0/6, na co wskazuje inna grubość murów zewnętrznych środkowej części od wschodniej (ryc. 4, pom. 0/6 a 0/7).

Obiekt oraz otaczający go teren w zastanym stanie technicznym oraz formie nie nadawał się do wykorzystania na cele publiczne - oświatowo-kulturalne. Konieczny był kompleksowy projekt i działania rewaloryzacyjne rehabilitacyjne, w celu dostosowania budynku do nowej funkcji użytkowej. Generalnego remontu i konserwacji oraz odświeżenia zasadniczo potrzebował cały budynek. Szczególnych prac remontowych wymagały fundamenty i dach budynku oraz ceglana, zabytkowa wieża, której według zaleceń Dolnośląskiego Wojewódzkiego Konserwatora Zabytków należało przywrócić funkcje widokową. 


\section{Stan techniczny i rehabilitacja}

Kondycja elementów nośnych była generalnie w dobrym stanie, nadającym się do dalszego użytku. Jednak, aby możliwa była adaptacja obiektu na nową, skądinąd prestiżową funkcję kulturalną, należało doprowadzić zabudowę do bardzo dobrego stanu technicznego i estetycznego. Konieczna była renowacja - rehabilitacja całego obiektu i poszczególnych jego części - elementów nośnych i konstrukcyjnych, wykończeniowych i wyposażenia, przeprowadzona według projektu wykonawczego zgodnego z obowiązującymi przepisami budowlanymi i normami.

Stan techniczny kamiennych fundamentów budynku był dobry. Także ceglane mury ścian oraz ław fundamentowych nie wykazały wyraźnych spękań. Jednak ze względu na brak izolacji wodnej i przeciwwilgociowej, przez kapilarne podciąganie wody gruntowej, ściany były znacznie zawilgocone. Dlatego wskazane było, po wcześniejszym odsłonięciu ścian fundamentowych, osuszenie i oczyszczenie powierzchni tychże murów oraz uzupełnienie spoin z zaprawy cementowo-wapiennej. Wykonano oczyszczenie i uzupełnienie ściany fundamentowej kamieniem i tynkiem rapowanym z dodatkiem środków uszczelniających. Na zewnątrz wykonano pionową izolację przeciwwilgociową, którą zabezpieczono przed mechanicznymi uszkodzeniami czarną, grubą folią ochronną. Dodatkowo wprowadzono poziomą izolację przeciwwilgociową w postaci papy termozgrzewalnej.

Fundamenty wieży wymagały dodatkowych prac ze względu na wyraźny brak stabilności konstrukcji, spowodowanym nierównomiernym osiadaniem gruntów, czego konsekwencją były widoczne spękania nie tylko fundamentów, ale także ścian. Pod ścianami wieży zaprojektowano poszerzenie istniejących fundamentów, mające ochronić ściany przed poszerzaniem się oraz ewentualnym pojawianiem się nowych pęknięć i zarysowań na murach nadziemnych, także nadproży otworów okien ostrołukowych. Stabilność budynku przede wszystkim uzależniona jest od fundamentów, dlatego te prace przeprowadzono ze szczególną starannością.
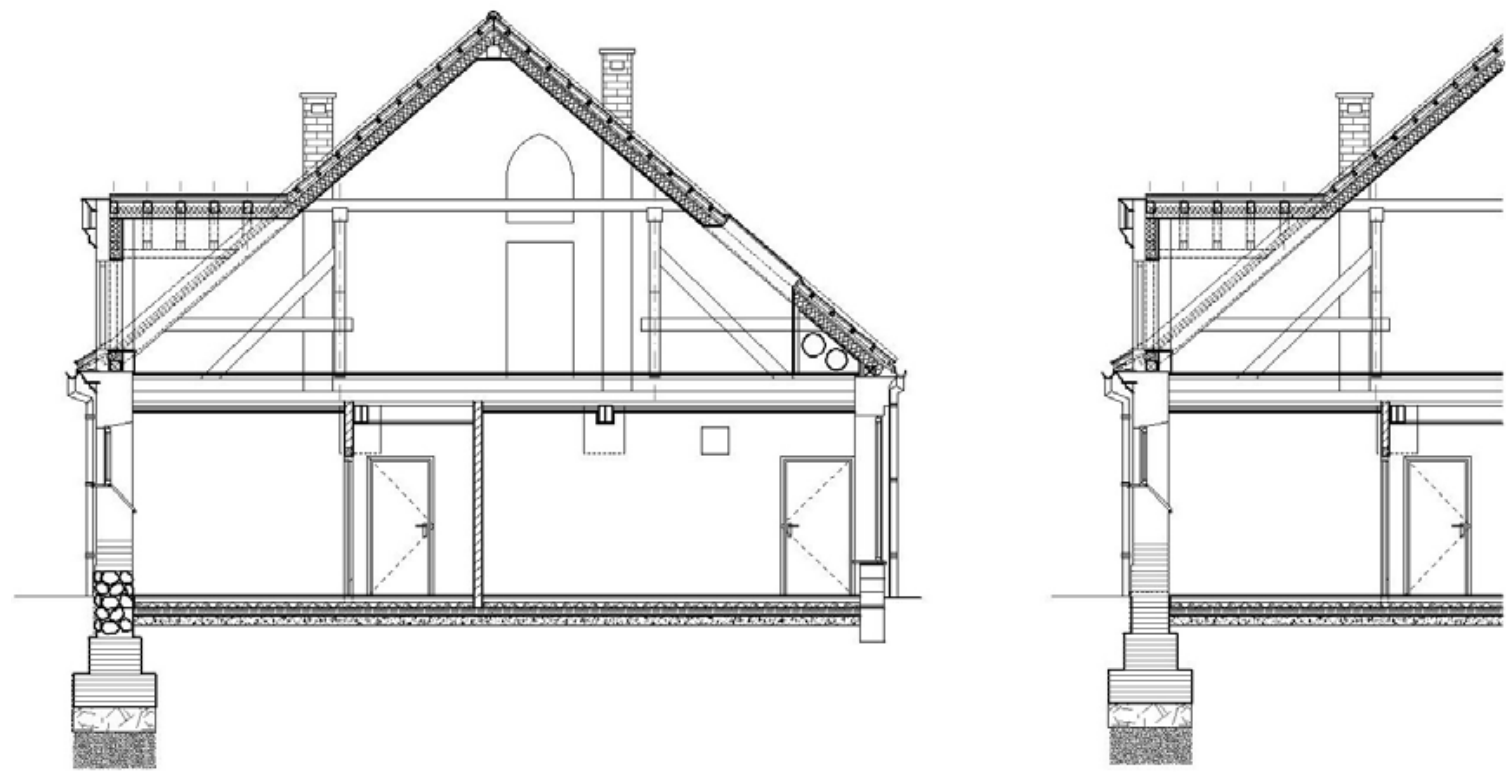

Ryc. 6. Przekroje poprzeczne: dwa typy ścian fundamentowych kamienne i ceglane, ceglanych fundamentów; Projekt wykonawczy, Rewitalizacja i adaptacja zabudowań dawnego folwarku (gotębnik) z przeznaczeniem na działalność Dolnobrzeskiego Ośrodka Kultury, główny projektant mgr inż. arch. Jacek Miller, rysunek Małgorzata Doroz-Turek, Wrocław 2011

Cross-sections: two types of foundation walls of stone and brick, the brick foundations; Executive project. Revitalization and adaptation of buildings of a former farm (dovecote) for the purpose of business Dolnobrzeskiego Cultural Centre, the chief designer arch. Jacek Miller, drawing Margaret Doroz Turek, Wroclaw 2011

Jeśli idzie o dach i jego drewnianą konstrukcję nośną, to z uwagi na w miarę dobry stan techniczny dużej części elementów drewnianych, mogły one zostać dalej wykorzystane. Jedynie niektóre elementy mocno skorodowane, z powodu niszczących skutków penetracji wody opadowej, wymagały wymiany na nowe, o takich samych 
gabarytach. Wszystkie drewniane elementy konstrukcyjne dachu zaimpregnowano przeciw grzybom, pleśniom i przeciw ogniowi. Na dachu w całości wymieniono ceramiczne pokrycie z dachówki karpiówki ułożonej podwójnie w łuskę wraz z wszystkimi obróbkami blacharskimi oraz systemem odwodnienia dachów (ryc. 6).

Na skutek wdzierania się wód opadowych przez nieszczelne pokrycie dachowe i z powodu braku odwodnienia dachu, uległa zniszczeniu część konstrukcji drewnianego stropu nad parterem. Tak jak w konstrukcji dachu wymieniono mocno zniszczone elementy, pozostałe poddano renowacji i konserwacji.

Na ceglanych ścianach elewacji i wewnątrz występował uszkodzony tynk, oprócz tego stwierdzono liczne ubytki cegły w partiach uskokowych oraz gzymsu wieńczącego. Ponadto na ścianach widoczne były również objawy zawilgocenia z powodu braku odwodnienia dachu oraz wentylacji wnętrz. Wszystkie tynki usunięto w celu osuszenia murów. Następnie lico zewnętrznych ścian, po dokładnym oczyszczeniu i uzupełnieniu ubytków, obłożono $3 \mathrm{~cm}$ warstwą tynku ciepłego, zaś wewnątrz zastosowano tynk renowacyjny oraz cementowo-wapienny grubości 1,5 cm. W miejscach występowania szczególnego ukształtowania elementów sztukatorskich, tj. cokołu, gzymsu pod okapem i podparapetowego, odtworzono je w miejscach, gdzie uległy zniszczeniu.

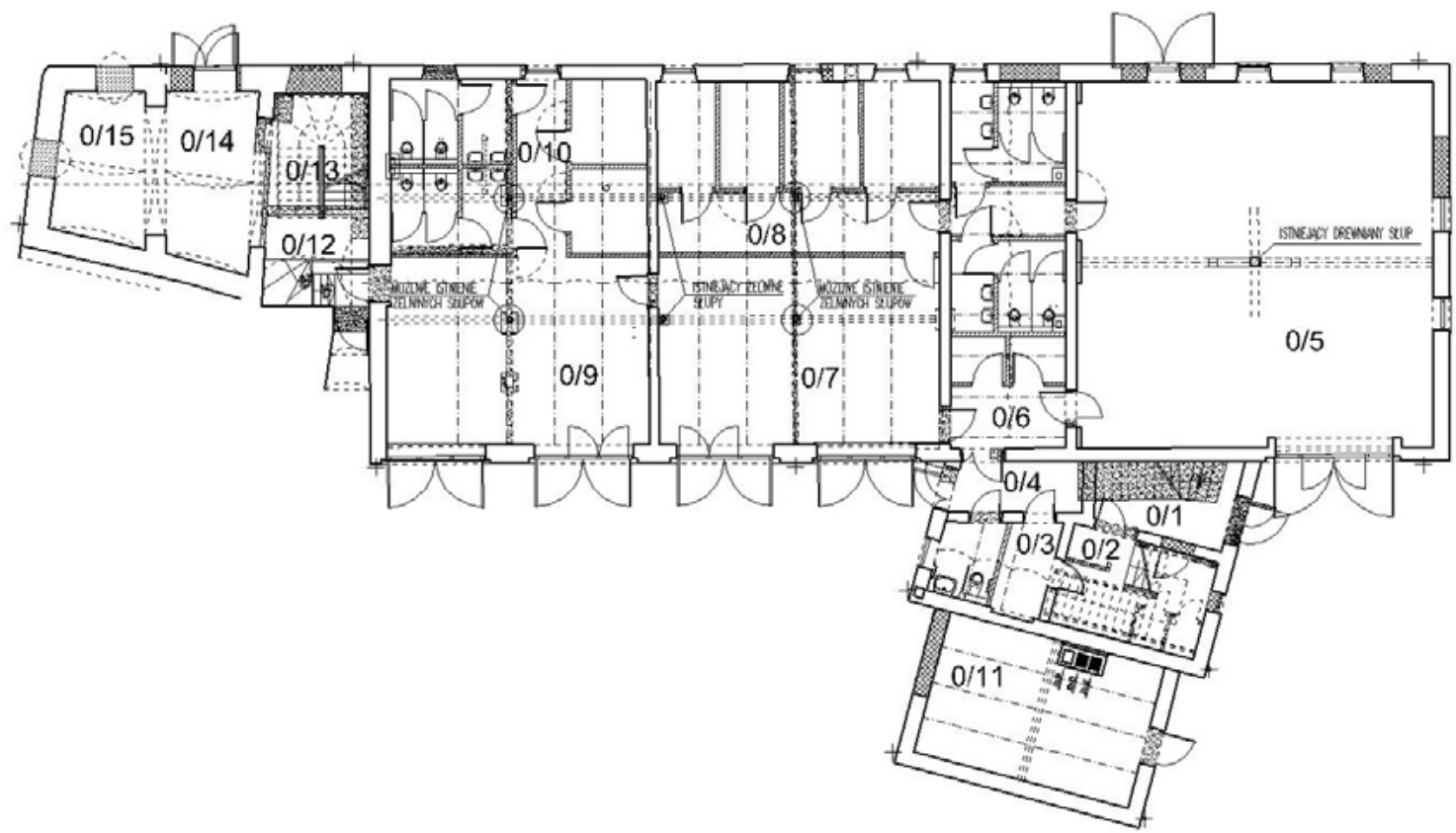

Ryc. 7. Rzut przyziemia; Projekt wykonawczy, Rewitalizacja i adaptacja zabudowań dawnego folwarku (gotębnik) z przeznaczeniem na działalność Dolnobrzeskiego Ośrodka Kultury, główny projektant mgr inż. arch. Jacek Miller, rysunek Małgorzata Doroz-Turek, Wrocław 2011

Ground plan; Executive project. Revitalization and adaptation of buildings of a former farm (dovecote) for the purpose of business Dolnobrzeskiego Cultural Centre, the chief designer arch. Jacek Miller, drawing Margaret Doroz Turek, Wroclaw 2011

\section{Projekt i realizacja}

Adaptacja pomieszczeń budynku dawnego Gołębnika na potrzeby Dolnobrzeskiego Domu Kultury obejmowała przyziemie budynku oraz trzy poziomy użytkowe wieży. Polegała na wpisaniu w istniejącą strukturę nowych funkcji uzgodnionych z Wojewódzkim Konserwatorem Zabytków we Wrocławiu. Ponadto był to projekt, który także musiał uwzględniać ustalenia Prawa Budowlanego, honorować wymogi instytucji sprawdzających: Straży 
Pożarnej, Stacji Sanitarno-Epidemiologicznej, inspekcji Bezpieczeństwa i Higieny Pracy, norm i rozporządzeń branżowych, sprostać współczesnym standardom i zapewnić funkcjonalną poprawność ${ }^{16}$.

Projektanci po zbadaniu obiektu, dokładnej inwentaryzacji, przystąpili do szczegółowego projektu rozplanowania podstawowych funkcji, które miały się znaleźć z założenia w obiekcie oraz im towarzyszących, koniecznych do spełnienia warunków prawa budowlanego i wszelkich norm. W największym pomieszczeniu, w południowo-zachodnim narożu budynku zaprojektowano przestronną salę do nauki tańca wyposażoną w profesjonalną drewnianą podłogę, pom. 0/5 (ryc. 7). W wąskim trakcie, pomiędzy dwoma istniejącymi nośnymi ścianami, wprowadzono zaplecze techniczno-sanitarne, pom. 0/6. Dalej, w kierunku wschodnim, z czterech pomieszczeń garażowych uzyskano dwie większe przestrzenie w których, we frontowym trakcie zaprojektowano salę zajęć tanecznych, pom. 0/7 oraz salę zajęć wokalnych, pom. 0/9 (ryc. 7). W tylnym trakcie rozwiązano pomieszczenia pomocnicze wraz z komunikacyjną, pom. 0/8 i 0/10 (ryc. 7). Bramy od frontu zastąpiono witrynami okiennymi doświetlającymi sale. Dwie wtórnie wprowadzone bramy, tak jak inne otwory, zostały zamurowane lub odtworzone w pierwotnym kształcie (ryc. 8).
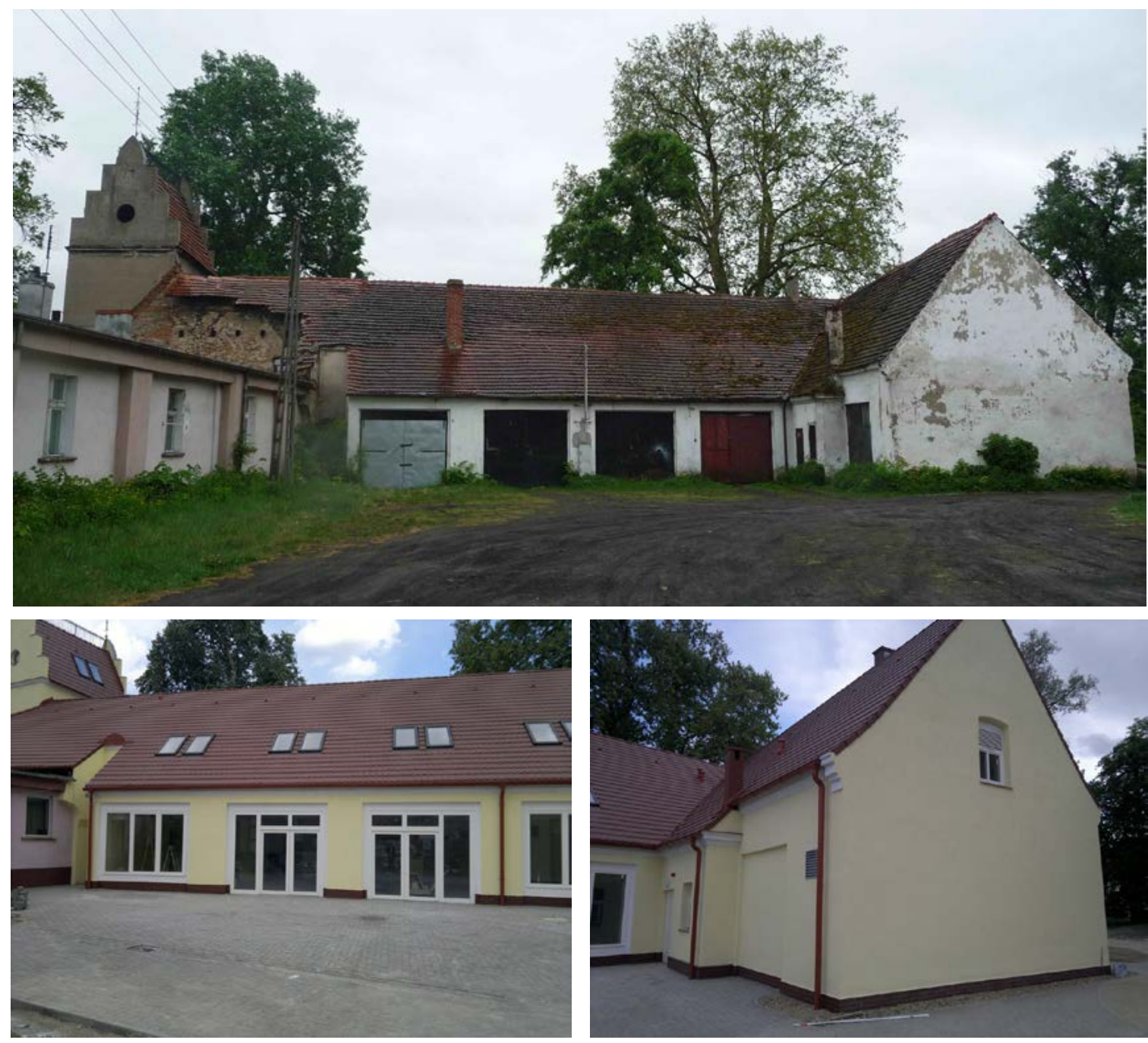

Ryc. 8. Widok obiektu od ulicy Kolejowej sprzed i po realizacji, foto autorki View of the object of Railway Street before and after the works, photo author 
Główne wejście do obiektu kulturalnego zostało zaprojektowane od strony dziedzińca w północnym, skośnie dobudowanym skrzydle. Od drugiej strony odtworzono szeroki otwór drzwiowy zamknięty półkoliście z drewnianymi drzwiami, wprowadzającymi do głównej klatki schodowej. Zamiast ceglanych schodów zaprojektowano nową, wygodną klatkę schodową prowadzącą na nieużytkowe poddasze. Poddasze oprócz odrestaurowanych lukarn zostało doświetlone oknami połaciowymi od frontu budynku (ryc. 9).
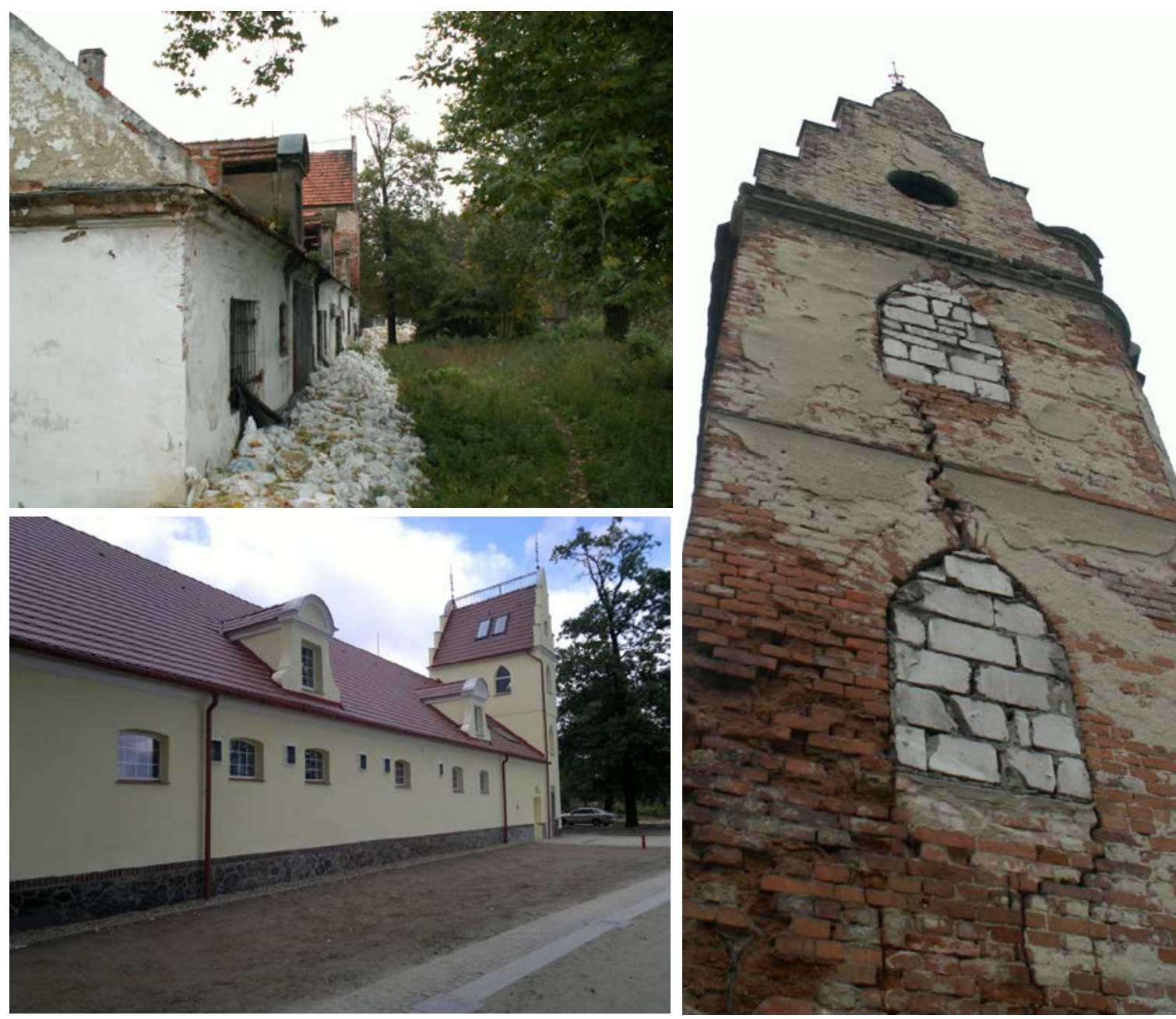

Ryc. 9. Widok obiektu od strony bulwaru wzdłuż koryta Odry sprzed i po realizacji, foto autorki View of the object from the boulevard along the Odra river before and after the works, foto author

Osobno została rozwiązana zasadnicza część budynku, związana z wieżą (pom. 0/12 / 0/15, ryc. 7). Do wschodniej części obiektu zaprojektowano dwa wygodne wejścia: jedno z dziedzińca, drugie od strony bulwaru nad Odrą. Szerokimi drzwiami wchodzimy do przesklepionego wnętrza, od którego w pomieszczeniu zaprojektowano drugie w stalowej konstrukcji schody. Komunikacja pionowa prowadzi na piętro na poziomie poddasza; gdzie hol przed wejściem do wieży. W wieży widokowej odtworzono schody prowadzące na dwa dalsze jej poziomy, skąd rozpościera się przez przywrócone ostrołucznie zamknięte okna widok na okolicę.

Projekt rewitalizacji i adaptacji Gołębnika obejmował zagospodarowanie terenu Folwarku związanego także z Wozownią, a musiał on uwzględniać również projekt dla całego zabytkowego kompleksu pałacowo-parkowego 
w Brzegu Dolnym realizowanym w ramach Projektu UrbSpace ${ }^{17}$. Dziedziniec między ulicą Kolejową a budynkiem Gołębnika zaprojektowano jako podjazd i parking ze strefą ruchu pieszego (ryc. 3). Po południowej stronie założenia architektonicznego, wzdłuż muru oporowego koryta rzeki Odry zaprojektowano także ciąg pieszy, którego trasa pokrywa się z przebiegiem ciągu spacerowego wzdłuż Odry zawartego w ww. opracowaniu UrbSpace.
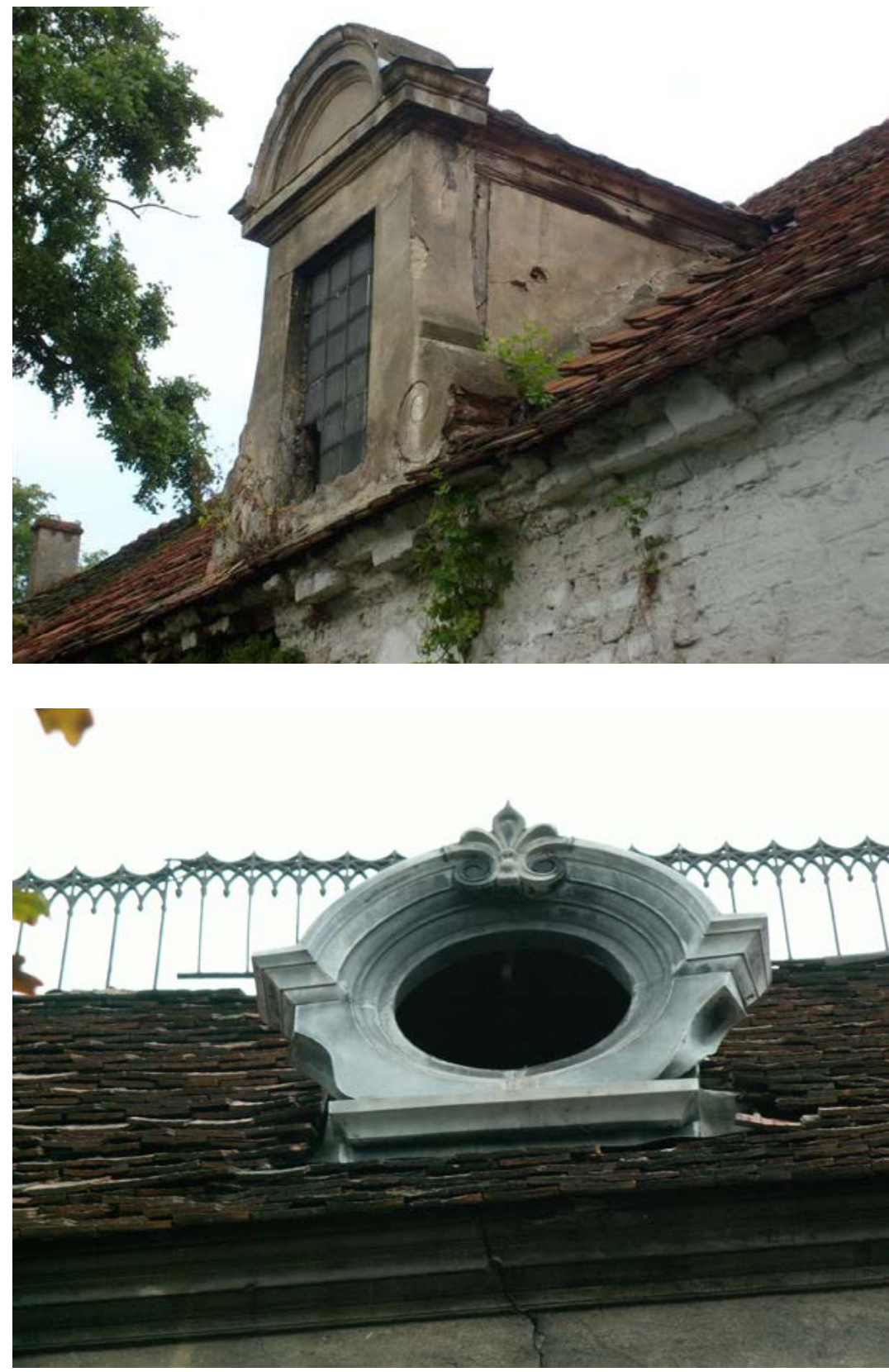

Ryc. 10. Lukarna na budynku, foto autorki

Dormer on the building, photo author
Ryc. 11. Lukarna na wieży, foto autorki

Dormer on the tower, photo author 


\section{Konkluzja}

Dziś Gołębnik jest siedzibą Dolnobrzeskiego Ośrodka Kultury. Poprzez nowe przeznaczenie utrzymano starą substancję i wartość tego miejsca, budynku tworzącego z pozostałymi obiektami zespół pałacowy, tj. dawna oficyna mieszkalna jest Urzędem Miejskim, zaś dawna stajnia i wozownia stały się Gminnym Ośrodkiem Pomocy Społecznej. Wszystkie służą miastu i jego mieszkańcom.

Pomysł wykorzystania istniejących obiektów zespołu pałacowego przerodził się w realizację, a ona stała się i nadal jest inspiracją kolejnych działań. Przedstawiona realizacja odzwierciedla przytoczony na początku cytat za Owidiuszem: „Cokolwiek czynisz, czyń rozważnie i patrz końca.”. Prace prowadzone od początku rozważnie i pomyślnie, można powiedzieć że nie mają jednak końca. Ciągle pojawiają się nowe pomysły, a inspiracją jest zastana, historyczna architektura potrzebująca często pomocy. Skuteczna rehabilitacja daje pozytywne efekty w „leczeniu" zabytkowej architektury, pozwalając na jej adaptację i dalsze bezpieczne użytkowanie.

\section{Piśmiennictwo}

[1] Chmielewska M., Żerelik R., 1989, Brzeg Dolny, Wrocław.

[2] Czyżniewska L., 2009,Uwagi dotyczące problemów adaptacji obiektów zabytkowych do wspótczesnych funkcji, [w:] Adaptacja obiektów zabytkowych do współczesnych funkcji użytkowych, praca zbiorowa pod red. Bogusława Szmygina, Warszawa-Lublin, s. 19-28.

[3] Kadłuczka A., 1999, Konserwacja zabytków i architektoniczne projektowanie konserwatorskie, Kraków.

[4] Kadłuczka A., 2000, Ochrona zabytków architektury. Zarys doktryn i teorii, t. 1, Stowarzyszenie Konserwatorów Zabytków, Kraków.

[5] Kaszuba E., Ziątkowski L., 1998, Historia Brzegu Dolnego, Brzeg Dolny, Wrocław.

[6] Kozioł I., Załęski J., 1992, Miasto i gmina Brzeg Dolny. Monografia krajoznawcza, Zeszyt 14, Wrocław.

[7] Szmelter I. M., 2006, Wspótczesna teoria konserwacji i restauracji dóbr kultury. Zarys zagadnień, [w:] Ochrona Zabytków, nr 2, s. 5-38.

[8] Projekt budowlany i wykonawczy, Rewitalizacja i adaptacja zabudowań dawnego folwarku (gotębnik) z przeznaczeniem na działalność Dolnobrzeskiego Ośrodka Kultury, główny projektant mgr inż. arch. Jacek Miller, 2011.

[9] Tajchman J., 2001, Adaptacja zabytków architektury w świetle wspótczesnej teorii ochrony i konserwacji dóbr kultury, [w:] Konserwacja, wzmacnianie i modernizacja budowlanych obiektów historycznych i współczesnych, Konferencja Naukowo-Techniczna, Kielce, s. 131-142.

[10] Wrabec H. i J., 1998, Zespót pałacowe-parkowy w Brzegu Dolnym (opinia naukowa), Wrocław.

[11] http://krasuski.com/o_rehabilitacji.html

[12] http://www.palaceslaska.pl/index.php?option=com_content\&view=article\&id=2025:radoszowy\&catid=26:r\&ltemid=59

\footnotetext{
Abstract: The theme of the article is the rehabilitation of monuments dedicated to adapt to the new feature, different from the first use. In the case of adaptation of old buildings, monuments of architecture, it is "carried out mainly within the framework of a comprehensive conservation and restoration activities," and rehabilitation is associated with a thorough renovation usually temporarily operated or abandoned and neglected buildings, a sufficient or very poor technical condition.

The author shows the rehabilitation and adaptation, as conservation activities, which play an important role engineering activities aimed at improving the state of the historic building, but maintaining the main principles of conservation.

An article about the rehabilitation of the building is devoted mainly Dovecote with tower, which consists on a former farm yard of the palace complex in the Brzeg Dolny, which the project the author took part.
}

Key words: rehabilitation of monuments, architecture, monument, restoration, adaptation 